\title{
End-Of-Life Care in Dementia among Asian, A Scoping Review
}

\author{
Firzanah Adabiah Z. ${ }^{1}$, Hana Maizuliana S., Nor Safiqah S., Abdul Aziz M. ${ }^{1}$, Ummu Aiman F. ${ }^{1}$, \\ Ummi Affah M. ${ }^{1,2}$ \\ ${ }^{1}$ Faculty of Medicine and Health Sciences, Universiti Sains Islam Malaysia, Nilai, Negeri Sembilan, Malaysia. \\ ${ }^{2}$ Pantai Hospital Kuala Lumpur, Kuala Lumpur, Malaysia
}

\section{ABSTRACT}

INTRODUCTION: Dementia is a neurocognitive disease characterised by a progressive deterioration of brain cognitive function. Dementia in the advanced stage should be treated as other terminal diseases. However, there is still a lack of acknowledgement regarding the end-of-life (EOL) care of people with dementia in Asian populations. This study aims to elucidate the components of EOL care in advanced dementia from the Asian perspective.

MATERIAL AND METHODS: Arksey and O'Malley's scoping review methodology framework was used to guide and conduct this scoping review. Databases of Pubmed, EBSCOhost, and Ovid Scholars were systematically searched using MeSH heading of end-of-life, palliative, dementia, and individual name of Asian countries.

RESULT: Fourteen articles met the inclusion criteria. The majority of the studies involved interviews or questionnaires to the caregivers, the patients, and the healthcare professionals. The studies were done mostly in Taiwan and Japan and one from Indonesia. The studies reported themes that were categorised into life sustenance treatments and medications, advanced directives, the burden of the caretakers, and the knowledge, attitude, and practice of the healthcare providers or the family members. CONCLUSION: Major barriers in delivering EOL care to advanced dementia patients include knowledge, skills, communication, attitude, and beliefs, especially among developing countries in Asia. More education and awareness are needed amongst the healthcare providers and the public regarding this matter to ensure proper EOL care in advanced dementia patients.

KEYWORDS: Palliative care, end-of-life care, dementia, Asian countries

\section{INTRODUCTION}

Dementia is a neurocognitive disease characterised by a progressive deterioration of brain cognitive function. ${ }^{1}$ As the population age, dementia is becoming more pronounced and alarming. ${ }^{2}$ Worldwide, there were an estimated 44 million people with dementia in 2013 and by 2030, 76 million people will have dementia. ${ }^{3}$ The prevalence of dementia in Asian countries is between

Corresponding Author:

Dr. Hana Maizuliana Solehan,

Faculty of Medicine and Health Sciences,

Universiti Sains Islam Malaysia,

Persiaran Ilmu, Putra Nilai,

71800, Nilai, Negeri Sembilan, Malaysia

Tel No: +60342892400

Email : drhana@usim.edu.my
0.03 and $33.2 \%$ and it is expected to increase significantly due to the rapid growth of aging populations. ${ }^{4}$ The most common form of dementia in the elderly is Alzheimer's disease (AD). ${ }^{5}$ Apart from cognitive decline, people with dementia also manifest changes in behaviour, thinking, and social interaction, in which significant alteration in theirs and the caregivers' lives. ${ }^{6}$ Advanced dementia is a terminal stage and described as severe loss of memory, loss of orientation to time, place, person, and ability to carry out daily living activities (ADL). ${ }^{7}$

The course of dementia is accelerating and unremitting, directing to death. ${ }^{8}$ Despite the presence of medical treatments that protracted the advancement of dementia, there is still no cure for it. ${ }^{9}$ Compared to 
other terminal diseases, proper end-of-life (EOL) care in patients with advanced dementia is still lacking. ${ }^{10}$ Patients with an advanced stage of dementia are often not recognised as having a terminal illness, resulting in poor EOL treatment or palliative care received.1,8 Globally, EOL care is grossly underdeveloped among patients with advanced dementia, particularly in Asia. ${ }^{11}$ The objective of this scoping review is to explore studies of EOL care in people with dementia among Asian countries.

\section{METHOD}

A scoping review was carried out to delineate the present literature and discover the extent, range, and nature of the research evidence associated with EOL care components in advanced dementia from an Asian perspective. This study emulates the five-phase framework for conducting scoping reviews by Arksey and O’Malley (2005). ${ }^{12}$

Stage 1: Identifying the research questions

What are the components of end-of-life care in people with advanced dementia from an Asian perspective?

What are the characters, types, and ranges of research in end-of-life care in advanced dementia patients among Asians?

Stage 2: Identifying relevant studies/search strategy

Electronic databases of Pubmed, EBSCOhost, and Ovid were systematically searched using various combinations of the following keywords "palliative" OR “end-of-life" OR "terminal" OR "hospice" AND "dementia" OR "Alzheimer's disease" OR "cognitive impairment" AND the individual name of Asian countries. Two reviewers (HM and FA) carefully went through the articles identified. Articles of observational studies, clinical trials, clinical case studies were included, whereas review articles, opinions, and brief communication were excluded.

\section{Stage 3: Study selection}

Studies conducted among the Asian population and advanced dementia patients were included. Other terminally ill conditions other than dementia, such as malignancy, end-stage kidney disease, or end-stage lung disease, were excluded. Only studies in the English language with available full articles were included.

\section{Stage 4: Collecting and analysing the data}

The parameters extracted from the materials for charting were characteristic of the study, including the year of publication, country of the study, types of study, and the number of samples. Their research objectives, methodologies, and findings were also analysed and documented.

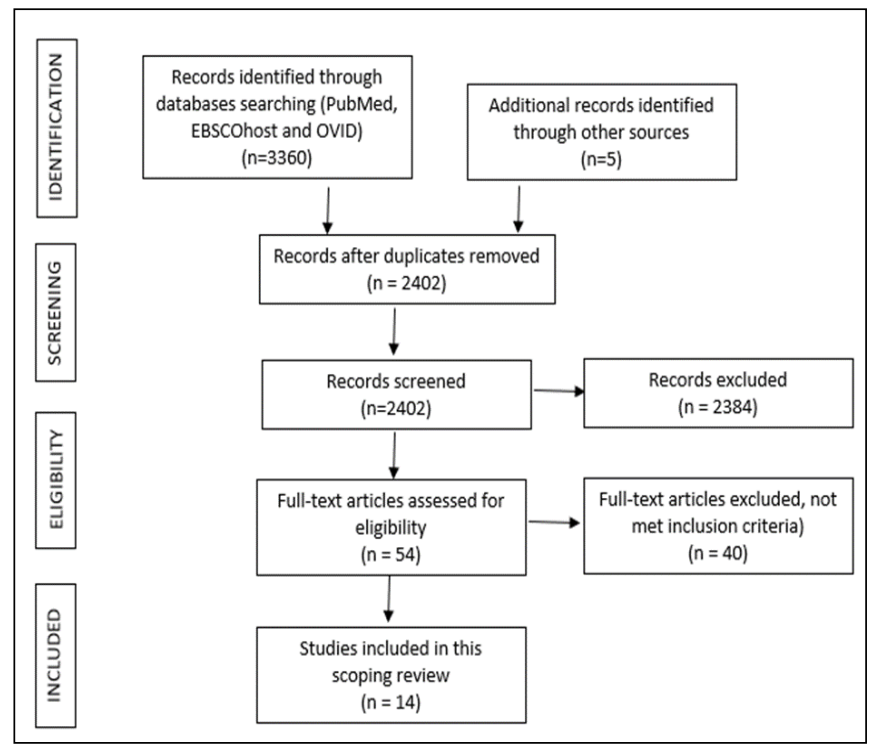

Figure 1. Flow diagram of this scoping review.

\section{RESULT}

Fourteen articles were included in this scoping review. The sample size varies in the number of respondents, ranging from 7 to 6532 due to each study's different methodologies. The studies were done mostly in Japan and Taiwan and one from Indonesia. The majority of the studies involved interviews or questionnaires to the caregivers, the patients, and the healthcare professionals. Twelve of the studies were cross-sectional studies, one retrospective case-control study, and one cohort study. Studies are conducted among older people with dementia, family members, healthcare professionals, group home administrators, and caregivers. Seven papers explored life sustenance treatments and medications and five studies reported advanced directives. Three articles revealed the caretakers' burden and five studies determined the knowledge, attitude, and practice of the healthcare providers or the family members. Some articles studying more than one theme. The summary of the selected papers is presented in Table I. 
Table I. Summary of articles included in this scoping review.

\begin{tabular}{|c|c|c|c|c|c|c|}
\hline No. & $\begin{array}{l}\text { Author } \\
\text { (year) }\end{array}$ & Country & $\begin{array}{l}\text { Types } \\
\text { of study }\end{array}$ & $\mathrm{n}$ & Main topic & Result \\
\hline 1. & $\begin{array}{l}\text { Chen et al } \\
(2018)^{13}\end{array}$ & Taiwan & Cohort study & 5988 & $\begin{array}{l}\text { Use of palliative care } \\
\text { and its association } \\
\text { with aggressive } \\
\text { treatment }\end{array}$ & $\begin{array}{l}\text { Palliative care contributes to a reduction } \\
\text { in LST in a patient with malignancy, } \\
\text { except increase usage of tube or enteral } \\
\text { feeding and ventilator in a patient with } \\
\text { dementia. }\end{array}$ \\
\hline 2. & $\begin{array}{l}\text { Chen et al } \\
(2002)^{14}\end{array}$ & Taiwan & Cross-sectional & 115 & $\begin{array}{l}\text { Preferred level of } \\
\text { EOL care }\end{array}$ & $\begin{array}{l}61 \% \text { of caregivers opt for highly } \\
\text { aggressive care, } \\
3 \% \text { opt for solely palliative care. }\end{array}$ \\
\hline 3. & $\begin{array}{l}\text { Nakanishi et al } \\
\quad(2016 \mathrm{a})^{15}\end{array}$ & Japan & Cross- sectional & 886 & $\begin{array}{l}\text { Use of medical } \\
\text { procedures in the last } \\
\text { month of life }\end{array}$ & $\begin{array}{l}\text { The majority of patients had EOL care in } \\
\text { the nursing home followed by hospitals } \\
\text { and own homes. }\end{array}$ \\
\hline 4. & $\begin{array}{l}\text { Kawasaki et al } \\
\quad(2015)^{16}\end{array}$ & Japan & Cross-sectional & 525 & $\begin{array}{l}\text { Knowledge of EOL } \\
\text { care options of both } \\
\text { laypeople and } \\
\text { healthcare } \\
\text { professionals }\end{array}$ & $\begin{array}{l}\text { The insignificant difference in perception } \\
\text { regarding gastrostomy vice versa to a } \\
\text { ventilator. }\end{array}$ \\
\hline 5. & $\begin{array}{l}\text { Nakanishi et al } \\
\quad(2009)^{17}\end{array}$ & Japan & Cross-sectional & 33 & $\begin{array}{l}\text { Processes of decision } \\
\text { making and EOL } \\
\text { care }\end{array}$ & $\begin{array}{l}\text { Family members decide the EOL care } \\
\text { and method of sustenance. }\end{array}$ \\
\hline 6. & $\begin{array}{l}\text { Chuang et al } \\
\qquad(2017)^{18}\end{array}$ & Taiwan & $\begin{array}{l}\text { Retrospective Case } \\
\text {-control }\end{array}$ & 6532 & $\begin{array}{l}\text { Medication } \\
\text { appropriateness for } \\
\text { patients with } \\
\text { dementia }\end{array}$ & $\begin{array}{l}10 \% \text { of patient with dementia received } \\
\text { "never appropriate" medications at EOL. }\end{array}$ \\
\hline 7. & $\begin{array}{l}\text { Nakanishi et al } \\
(2016 \mathrm{~b})^{19}\end{array}$ & Japan & Cross-sectional & 2116 & $\begin{array}{l}\text { Association between } \\
\text { care quality and } \\
\text { professional caregiv- } \\
\text { ers' perspectives } \\
\text { regarding palliative } \\
\text { care for dementia }\end{array}$ & $\begin{array}{l}\text { Increment in patient's quality of life was } \\
\text { directly linked to professional caregivers' } \\
\text { knowledge and attitudes. }\end{array}$ \\
\hline 8. & $\begin{array}{l}\text { Huang et al } \\
(2018)^{20}\end{array}$ & Taiwan & Cross-sectional & 143 & $\begin{array}{l}\text { Factors influence the } \\
\text { presence of advance } \\
\text { directives for nursing } \\
\text { home residents }\end{array}$ & $\begin{array}{l}\text { Policies in a nursing home, religious } \\
\text { beliefs, and decisions by surrogate influ- } \\
\text { ence the presence of advance directives. }\end{array}$ \\
\hline 9. & $\begin{array}{l}\text { Tsai et al } \\
(2015)^{21}\end{array}$ & Taiwan & Cross-sectional & 168 & $\begin{array}{l}\text { Disagreements on } \\
\text { LST preferences }\end{array}$ & $\begin{array}{l}\text { High disagreement rate between patient } \\
\text { and caregivers on LST because of depres- } \\
\text { sion among caregivers. }\end{array}$ \\
\hline 10. & $\begin{array}{l}\text { Huang et al } \\
(2018)^{22}\end{array}$ & Taiwan & $\begin{array}{l}\text { Cross-sectional } \\
\text { and correlational } \\
\text { study }\end{array}$ & 478 & $\begin{array}{l}\text { Factors related to } \\
\text { the EOL care } \\
\text { discussions }\end{array}$ & $\begin{array}{l}\text { Knowledge, attitude, confidence, com- } \\
\text { munication skills towards palliative care } \\
\text { lead to a more frequent discussion on } \\
\text { EOL care. }\end{array}$ \\
\hline 11. & $\begin{array}{l}\text { Kristanti et al } \\
\quad(2018)^{23}\end{array}$ & Indonesia & Cross-sectional & 25 & $\begin{array}{l}\text { Lived experiences of } \\
\text { family caregivers of } \\
\text { PWC and PWD. }\end{array}$ & $\begin{array}{l}\text { Similar aspects between PWC and PWD: } \\
\text { difficulties in caregiving, facing the prob- } \\
\text { lems and belief of EOL care. }\end{array}$ \\
\hline 12. & $\begin{array}{l}\text { Kobayashi et al } \\
\quad(2008)^{24}\end{array}$ & Japan & Cross- sectional & 7 & $\begin{array}{l}\text { Components of EOL } \\
\text { care }\end{array}$ & $\begin{array}{l}\text { Maintain their lifestyle, reduce physical } \\
\text { and mental discomfort, maximize delivery } \\
\text { of medical care and cooperate with family } \\
\text { members. }\end{array}$ \\
\hline 13. & $\begin{array}{l}\text { Nakanishi et al } \\
\quad(2016 \mathrm{c})^{25}\end{array}$ & Japan & Cross-sectional & 275 & $\begin{array}{l}\text { Knowledge and } \\
\text { attitudes of nursing } \\
\text { home staff regarding } \\
\text { palliative care of } \\
\text { advanced dementia }\end{array}$ & $\begin{array}{l}\text { Greater knowledge and positive attitudes } \\
\text { were seen in facilities that established a } \\
\text { manual for end-of-life care. }\end{array}$ \\
\hline 14. & $\begin{array}{l}\text { Chen et al } \\
(2018)^{26}\end{array}$ & Taiwan & Cross sectional & 300 & $\begin{array}{l}\text { Knowledge and } \\
\text { attitudes toward } \\
\text { palliative care for } \\
\text { advanced dementia }\end{array}$ & $\begin{array}{l}\text { Working experience and an adequate } \\
\text { training on palliative care associated with } \\
\text { greater knowledge and attitude. }\end{array}$ \\
\hline
\end{tabular}

EOL, End-of-life; PWC, Patients with cancer; PWD, Patients with dementia; ANH, Artificial nutrition, and hydration; Life-sustenance treatment, LST. 


\section{DISCUSSION}

Increasing awareness of EOL care application should be parallel with the appropriateness of the treatment received by the patient with advanced dementia. However, the application and knowledge are still much lacking in Asian countries.27,28 Effectiveness in delivering EOL care and treatment to people with dementia requires sound knowledge, attitude, skill, and experience. The attitude in perceiving dementia as a terminal disease is not strong as other terminal diseases.7,29 Previous studies in Europe point out that the majority of senior people with good cognition rejected CPR if they were to receive it in their EOL care $^{30}$ and almost $95 \%$ of family members refused CPR for their dementia care recipients. ${ }^{31}$ Lack of awareness among the family members in delivering EOL care in people with dementia necessitates further intervention to improve patients and their caregivers' quality of life. ${ }^{32}$ Knowledge and information regarding the medical intervention should be highlighted among the family members for making the best decision for the patient.

The research of dementia caregiver's burden is limited, ${ }^{33-35}$ however, there is evidence that the burden escalates towards the later stage of dementia. ${ }^{34}$ Caregivers of dementia patients experience similar problems and burden symptoms as cancer patients' carer; therefore, they need to be given equal support. $23,36,37$ Especially in dementia EOL care, it should relieve the patient's symptoms and involve the caregivers' comfort who have been suffering for long and should not be regarded as less significant. ${ }^{37}$ More so, the quality of EOL care of patients dying from dementia is less supported by the palliative care physician than EOL care of cancer patients as reported by a European study. ${ }^{37}$ Another study in the United Kingdom, reported that advanced dementia patients were not referred to palliative physicians as much as other non-cancer end-stage illnesses and they were prescribed lesser medication for palliation. ${ }^{38}$

A nursing home is one of the feasible substitutes other than home care for people with dementia. ${ }^{39}$ Caring for people with dementia in nursing homes has been one of the options listed by their caregivers. The decision of placement is made based on the higher Clinical Dementia Rating (CDR) score. ${ }^{14}$ A right nursing home made a more significant impact on their residents' wellbeing. The collaboration of nursing homes with competent physicians in implementing EOL treatment and cooperation with the family members will produce an excellent framework in the EOL care of people with dementia. However, nursing homes are only capable of handling mild to moderate cases of people with dementia. Extra guidance on managing dementia cases in the advanced stage, equipment of the staff with knowledge and involvement of medical personnel in the late stage, still has not been reinforced. Application on advance care planning (ACP) proved higher satisfaction to all parties and should be included in discussion and implementation of EOL care in nursing home. ${ }^{40}$

One of the essential keys in EOL care of people with dementia is advance directives. This measure-count on patients' capacity in deciding for themselves. Advance directives grant all parties satisfaction in giving and receiving EOL care in people with dementia. ${ }^{41}$ Possess an advanced directive may significantly impact the attitude of healthcare providers and their decision whether to deliver LST or vice versa, despite knowing the prognosis of the illness. ${ }^{42}$ Effective communication and discussion between healthcare professionals and patients with dementia can produce well-founded and reasonable advance directives. ${ }^{43}$ In comparison between people with dementia and other terminal diseases, lesser people with dementia have advance directives. ${ }^{44,45}$ Advance directives are indirectly linked to lessen the burdens carried by the caregivers. However, their caregivers' preference in EOL care is based on their caregivers' preference ${ }^{46}$ and the study revealed they imprecisely anticipate patient preferences. ${ }^{47}$

The decision on the place of death and method of sustenance in the EOL care should be followed concerning the patient's wish. However, most of the time, the decision regarding this matter will follow the family member's wish instead, as it is hard to recognize the genuine desire of patients with dementia 48 . The majority of the patients opted for dying at their own house in contrast to family members' choice at the group home. ${ }^{17}$ Therefore, managing directors should consult the patients first, in the beginning, to address the EOL care issues before seeking family members' wishes. 
There are a few aspects that were not addressed in the available studies. One of the most essential elements in assessing the quality of EOL care delivered to people with dementia. The assessment tools include End-ofLife in Dementia (EOLD) scales, which comprise of satisfaction with the terminal care (SWC-EOLD); symptom management (SM-EOLD), and comfort during the last seven days of life (CAD-EOLD). ${ }^{49}$ Better recognition of the quality of care can be achieved if these tools' function is fully maximized. Secondly, no study identifies financial aspects such as cost of care, tax reimbursement, or insurance policy of advanced dementia people. This economic perspective is particularly more important in delivering good end-oflife care as most dementia patients are financially dependent on the caregiver or family member. Other aspects that possibly need to be explored are knowledge of ethics and law, a continuation of care and integration with related organisations, and government policies.

We have found that palliative care in advanced dementia patients was not reported in the majority of Asian countries. Diverse cultural background among the Asian population likely results in various findings that would be important and interesting to be uncovered. EOL care in advanced dementia is getting more attention among healthcare professionals, caregivers, nursing staff, family, and patients with dementia themselves. Perhaps, extensive collaboration with multiple relevant agencies for further research and reports should be carried out soon, particularly among Asian countries to overcome the barriers in delivering EOL care to people with dementia.

\section{CONFLICT OF INTEREST}

The authors declare that there is no conflict of interest in this paper.

\section{ACKNOWLEDGEMENT}

We thank the faculty staffs for their assistance in this project. Our appreciation also goes to the Research and Innovation Management Center, Universiti Sains Islam Malaysia (USIM) for their financial support (Grant no: PPPI/FPSK/0217/051000/12818)
1. Hugo J, Ganguli M. Dementia and cognitive impairment: epidemiology, diagnosis, and treatment. Clin Geriatr Med 2014;30(3):421-442.

2. Rizzi L, Rosset I, Roriz-Cruz M. Global epidemiology of dementia: Alzheimer's and vascular types. Biomed Res Int 2014;2014.

3. International AD. World Alzheimer Report 2018. The state of the art of dementia research: New frontiers. Published online 2018.

4. Catindig J-AS, Venketasubramanian N, Ikram MK, et al. Epidemiology of dementia in Asia: insights on prevalence, trends and novel risk factors. J Neurol Sci 2012;321(1-2):11-16.

5. World Health Organization. Dementia. Published 2019. Accessed August 10, 2020. https:// www.who.int/news-room/fact-sheets/detail/ dementia

6. Cerejeira J, Lagarto L, Mukaetova-Ladinska E. Behavioral and psychological symptoms of dementia. Front Neurol 2012;3:73.

7. Mitchell SL, Teno JM, Kiely DK, et al. The clinical course of advanced dementia. $N$ EnglJ Med 2009;361(16):1529-1538.

8. Kane PM, Daveson BA, Ryan K, et al. The need for palliative care in Ireland: a population-based estimate of palliative care using routine mortality data, inclusive of nonmalignant conditions. J Pain Symptom Manage 2015;49(4):726-733.

9. Buffum MD, Buffum JC. Dementia treatment update. Geriatr Nurs (Minneap). 2006;26(3):138-142.

10. Mitchell SL, Kiely DK, Hamel MB. Dying with advanced dementia in the nursing home. Arch Intern Med 2004;164(3):321-326.

11. Spruyt O. The status of palliative care in the AsiaPacific Region. Asia-Pacific J Oncol Nurs 2018;5 (1):12.

12. Arksey H, O'Malley L. Scoping studies: towards a methodological framework. Int J Soc Res Methodol 2005;8(1):19-32.

13. Chen P-J, Liang FW, Ho CH, et al. Association between palliative care and life-sustaining treatments for patients with dementia: A nationwide 5-year cohort study. Palliat Med 2018;32(3):622-630.

14. Chen WTT, Wang SJ, Lu SR, et al Which level of care is preferred for end-stage dementia? Survey of

IMJM Volume 20 No.2, Apr 2021 
Taiwanese caregivers. I Geriatr Psychiatry Neurol 2002;15(1):16-19.

15. Nakanishi M, Nakashima T, Shindo Y, et al. Japanese Care Location and Medical Procedures for People with Dementia in the Last Month of Life. J Alzheimers Dis 2016;51(3):747-755.

16. Kawasaki A, Matsushima M, Miura Y, et al.

Recognition of and intent to use gastrostomy or ventilator treatments in older patients with advanced dementia: differences between laypeople and healthcare professionals in Japan. Geriatr Gerontol Int 2015;15(3):318-325.

17. Nakanishi M, Honda T. Processes of decision making and end-of-life care for patients with dementia in group homes in Japan. Arch Gerontol Geriatr.2009;48(3):296-299.

18. Chuang HY, Wen YW, Chen LK, et al. Medication appropriateness for patients with dementia approaching the end of their life. Geriatr Gerontol Int 2017;17:65-74.

19. Nakanishi M, Hirooka K, Morimoto $Y$, et al. Quality of care for people with dementia and professional caregivers' perspectives regarding palliative care in Japanese community care settings. Int J Geriatr Psychiatry 2017;32(12):1342-1351.

20. Huang H-L, Shyu Y-IL, Weng L-C, et al. Predictors of advance directives among nursing home residents with dementia. Int psychogeriatrics 2018;30(3):341-353.

21. Tsai CF, Lee YT, Lee WJ, et al. Depression of Family Caregivers Is Associated with Disagreements on Life-Sustaining Preferences for Treating Patients with Dementia. PLoS One 2015;10(7):e0133711.

22. Huang HL, Weng LC, Hu WY, et al. End-of-Life Care Discussion for Residents With Dementia in Long-Term Care Facilities. J Nurs Res 2018;26 (4):231-241.

23. Kristanti MS, Engels Y, Effendy C, et al. Comparison of the lived experiences of family caregivers of patients with dementia and of patients with cancer in Indonesia. Int Psychogeriatrics 2018;30(6):903-914.

24. Kobayashi S, Yamamoto-Mitani N, Nagata S, et al. End-of-life care for older adults with dementia living in group homes in Japan. Jpn J Nurs Sci 2008;5(1):31-40.
25. Nakanishi M, Miyamoto Y. Palliative care for advanced dementia in Japan: knowledge and attitudes. Br J Nurs 2016;25(3):146-155.

26. Chen IH, Lin KY, Hu SH, et al. Palliative care for advanced dementia: Knowledge and attitudes of long-term care staff. J Clin Nurs 2018;27(3-4):848858.

27. Lim WS, Wong SF, Leong I, et ak. Forging a Frailty-Ready Healthcare System to Meet Population Ageing. Int J Environ Res Public Health 2017;14(12).

28. Luk JKH, Chan FHW. End-of-life care for advanced dementia patients in residential care home-a Hong Kong perspective. Ann Palliat Med 2018;7(3):359-364.

29. Marcus E-L, Golan O, Goodman D. Ethical Issues related to End of Life Treatment in Patients with Advanced Dementia-The Case of Artificial Nutrition and Hydration. Diametros 2016;(50):118137.

30. Schonwetter RS, Walker RM, Solomon M, et al. Life values, resuscitation preferences, and the applicability of living wills in an older population. $J$ Am Geriatr Soc 1996;44(8):954-958.

31. Luchins DJ, Hanrahan P. What is appropriate health care for end-stage dementia? I Am Geriatr Soc 1993;41(1):25-30.

32. Torke AM, Holtz LR, Hui S, et al. Palliative care for patients with dementia: a national survey. $J \mathrm{Am}$ Geriatr Soc 2010;58(11):2114-2121.

33. de Vugt ME, Riedijk SR, Aalten P, et al. Impact of behavioural problems on spousal caregivers: a comparison between Alzheimer's disease and frontotemporal dementia. Dement Geriatr Cogn Disord 2006;22(1):35-41.

34. Mioshi E, Foxe D, Leslie F, et al. The impact of dementia severity on caregiver burden in frontotemporal dementia and Alzheimer disease. Alzheimer Dis Assoc Disord 2013;27(1):68-73.

35. Wang J, Xiao LD, He GP,et al. Factors contributing to caregiver burden in dementia in a country without formal caregiver support. Aging Ment Heal 2014;18(8):986-996.

36. Costa-Requena G, Espinosa Val MC, Cristòfol R. Caregiver burden in end-of-life care: advanced cancer and final stage of dementia. Palliat Support Care 2015;13(3):583-589. 
37. Piers R, Pautex S, Curale V, et al. Palliative care for the geriatric patient in Europe. Z Gerontol Geriatr 2010;43(6):381-385.

38. Sampson EL, Jones L, Thuné-Boyle IC V, et al. Palliative assessment and advance care planning in severe dementia: an exploratory randomized controlled trial of a complex intervention. Palliat Med 2010;25(3):197-209.

39. Lithgow S, Jackson GA and Browne D. Estimating the prevalence of dementia : cognitive screening in Glasgow nursing homes. Int J Geriatr Psychiatry 2011;27(8):785-791.

40. Liu LM, Guarino AJ and Lopez R. Family Satisfaction With Care Provided by Nurse Practitioners to Nursing Home Residents With Dementia at the End of Life. Clin Nurs Res 2012;21 (3):350-367.

41. Jethwa KD, Onalaja O. Advance care planning and palliative medicine in advanced dementia: a literature review. BJPsych Bull 2015;39(2):74-78.

42. Ahronheim JC, Morrison RS, Morris J et al. Palliative Care in Advanced Dementia : A Randomized Controlled Trial and Descriptive Analysis. J Palliat Med 2000;3(3).

43. Hegde S, Ellajosyula R. Capacity issues and decision-making in dementia. Ann Indian Acad Neurol 2016;19(Suppl 1):S34.

44. Ouldred, E, Bryant C. Dementia care. Part 3: endof-life care for people with advanced dementia. Br J Nurs 2008;17(5):5-10.

45. Thuné-Boyle IC V, Sampson EL, Jones L, et al. Challenges to improving end of life care of people with advanced dementia in the UK. Dementia 2010;9(2):259-284.

46. Fagerlin A, Danks JH, Ditto PH, et al. Projection in Surrogate Decisions About Life-Sustaining Medical Treatments. Heal Psychol 2001;20(3):166175.

47. Shalowitz DI, Garrett-Mayer E, Wendler D. The accuracy of surrogate decision makers: a systematic review. Arch Intern Med 2006;166(5):493-497.

48. Lamberg JL, Person CJ, Kiely DK, et al. Decisions to Hospitalize Nursing Home Residents Dying with Advanced Dementia. I Am Geriatr Soc 2005;53:1396-1401.
49. Kiely DK, Volicer L, Teno J, et al. The validity and reliability of scales for the evaluation of end-of-life care in advanced dementia. Alzheimer Dis Assoc Disord 2006;20(3):176. 